2010

\title{
The Breakdown of the Rule of Law in Sri Lanka: An Overview
}

James Yap

Craig Scott

Osgoode Hall Law School of York University

Follow this and additional works at: https://digitalcommons.osgoode.yorku.ca/all_papers

Part of the Comparative and Foreign Law Commons

\section{Repository Citation}

Yap, James and Scott, Craig, "The Breakdown of the Rule of Law in Sri Lanka: An Overview" (2010). All Papers. 268.

https://digitalcommons.osgoode.yorku.ca/all_papers/268

This Working Paper is brought to you for free and open access by the Research Papers, Working Papers, Conference Papers at Osgoode Digital

Commons. It has been accepted for inclusion in All Papers by an authorized administrator of Osgoode Digital Commons. 


\title{
The Breakdown of the Rule of Law in Sri Lanka: An Overview
}

\author{
James Yap \& Craig Scott*
}

Sri Lanka Campaign for Peace and Justice

September 22, 2010

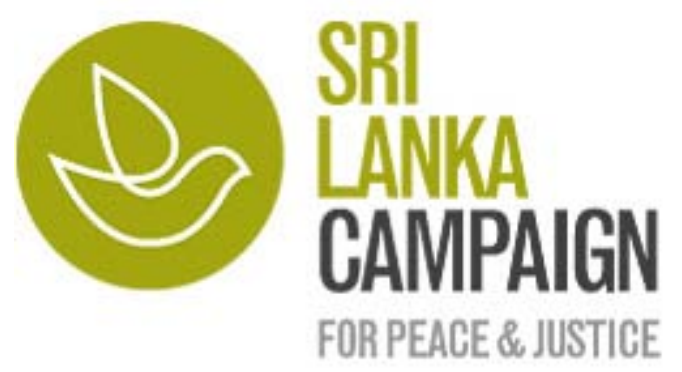

WWW.SRILANKACAMPAIGN.ORG

\footnotetext{
* James Yap is currently Law Clerk for Justice Ian Binnie of the Supreme Court of Canada. Craig Scott is Professor of Law, Osgoode Hall Law School, and Director of the Nathanson Centre on Transnational Human Rights, Crime and Security of York University; he is also a member of the Advisory Council of the Sri Lanka Campaign on Peace and Justice. James Yap’s contribution, forming the bulk of the document, was written while research assistant for Professor Scott, and prior to taking up his current position. The research and editorial assistance of Sri Lanka Campaign volunteers is greatly appreciated. For information on the Campaign, see http://www.srilankacampaign.org.
} 
When liberties are taken away and when democratic institutions die, is it even worse than human beings dying? This is the query that came to my mind when writing to a colleague and friend this Wednesday. His immediate answer, that when institutions die, people end up living as if they are dead, touched a raw nerve.

- Kishali Pinto-Jayawardena,

September $12,2010^{1}$

There has been a deafening global silence in response to Sri Lanka's actions, especially from its most influential friends. The international community cannot be selective in its approach to upholding the rule of law and respect for human rights. Impunity anywhere is a threat to international peace and security everywhere.

- Kofi Annan, former United Nations Secretary-General and Member, The Elders,

August 3, $2010^{2}$

\section{Introduction}

This overview analyzes the state and the underlying causes of the current breakdown of the rule of law in Sri Lanka. The information herein is drawn primarily (but not exclusively) from three sources:

\footnotetext{
1 "Death chant for democracy,” The Sunday Times (of Sri Lanka), September 12, 2010, at http://sundaytimes.lk/100912/Columns/focus.html.
}

${ }^{2}$ Statement made as part of The Elders' Media Relapse, Sri Lanka's disturbing actions met by 'deafening global silence', 3 Aug 2010, available at http://theelders.org/media/mediareleases/sri-lankas-disturbingactions-met-by-deafening-global-silence. The Elders are an independent group of global leaders, brought together by Nelson Mandela in 2007, who offer their collective influence and experience to support peacebuilding, help address major causes of human suffering and promote the shared interests of humanity. The Elders are Martti Ahtisaari, Kofi Annan, Ela Bhatt, Lakhdar Brahimi, Gro Brundtland, Fernando Henrique Cardoso, Jimmy Carter, Graça Machel, Mary Robinson and Desmond Tutu (Chair). Nelson Mandela and Aung San Suu Kyi are honorary Elders. The Media Release starts with the following paragraph: "The Sri Lankan government's clampdown on domestic critics and its disdain for human rights deserves a far tougher response according to The Elders. While welcoming the end of the decadeslong civil war, the Elders say that meaningful progress on reconciliation in Sri Lanka is still desperately needed. They describe the international response to Sri Lanka's worrying approach to human rights, good governance and accountability as a 'deafening global silence' that may encourage other states to act in a similar way.” Annan's statement was accompanied by statements from other Elders, including Martti Ahtisaari, former President of Finland, who said: "Countries operating outside international norms watch each other carefully. They will be taking courage from Sri Lanka's apparent success at avoiding international reproach. This is a worry for all those who want to see more democracy, greater respect for human rights and less violence in the world." 
- Basil Fernando, Sri Lanka: Impunity, Criminal Justice \& Human Rights (Asian Human Rights Commission: Hong Kong, 2010) ${ }^{3}$

- Justice in retreat: A report on the independence of the legal profession and the rule of law in Sri Lanka (International Bar Association Human Rights Institute [IBAHRI]: London May 2009) ${ }^{4}$

- Kishali Pinto-Jayawardena, The Rule of Law in Decline in Sri Lanka- Study on the Prevalence, Determinants and Causes of Torture and Other Forms of Cruel, Inhuman and Degrading Treatment (Rehabilitation and Research Centre for Torture Victims: Copenhagen, 2009) ${ }^{5}$

The Pinto-Jayawardena report provides a detailed analysis of the causes behind the breakdown of the rule of law in Sri Lanka, while Fernando's work provides a conceptual and critical analysis of overarching themes that is extremely useful for understanding the situation in Sri Lanka. Facts and figures were also drawn from a wealth of other reports and analyses published by a range of actors, including Amnesty International, Human Rights Watch, the International Commission of Jurists, Reporters Without Borders, the International Crisis Group, United Nations Human Rights Council Special Rapporteurs, the European Union, and the Office of War Crimes Issues of the United States Department of State. ${ }^{6}$

In Sri Lanka: Impunity, Criminal Justice and Human Rights, Basil Fernando describes the current situation in Sri Lanka as one of “abysmal lawlessness”. Lawlessness of this sort differs from simple illegality or disregard for law, which to differing degrees can happen anywhere. Lawlessness is abysmal when law ceases to be a reference at all. What would

\footnotetext{
${ }^{3}$ Available for download at http://www.ahrchk.net/pub/mainfile.php/slimpunity/.

${ }^{4}$ Available for download at http://www.ibanet.org/Article/Detail.aspx?ArticleUid=7df2962f-7769-4faf$\underline{\text { 8e16-6371b408c174. }}$

${ }^{5}$ Available for download at http://www.ruleoflawsrilanka.org/resources/THE-RULE-OF-LAW-OFDECLINE.pdf/view. For information on the Rehabilitation and Research Centre for Torture Victims, see http://www.uk.rct.dk.

${ }^{6}$ See the various sources cited throughout this document. The purpose of this brief overview is not to duplicate the wealth of detail found in these other reports, and the occasional examples used in this overview represent merely the tip of the iceberg. For that reason, readers are encouraged to consult these reports, most of which have executive summaries; the web addresses of each source are part of each citation.
} 
normally be crime ceases to be thought of as crime and lawlessness becomes routine. Of special relevance to the theme of the breakdown of the rule of law is that, under circumstances of abysmal lawlessness, the concept of legal redress - which is vital to the proper functioning of any legal system - has in fact been completely decoupled from whatever may be called law. In Sri Lanka, the primary cause of this decoupling has been the fundamental failure of the institutions responsible for the implementation of legal redress.

Sri Lanka's justice and accountability institutions have been eroded to the point that they have become not simply dysfunctional but also sham institutions - institutions that are little more than hollow impressions that merely approximate some of the external characteristics of genuine, functional institutions. Sri Lanka does not lack for a constitution, a court system, and other formal mechanisms for legal redress; however, none of these institutions have much more depth or substance to them than a Hollywood film set. In other writing, Fernando has invoked the medical metaphor of the phantom limb to evocatively convey this chasm between appearance and reality with respect to the institutions of Sri Lanka's legal system:

A medical doctor who attended a presentation I made on the absence of institutions for administrations of justice and its impact on human rights suggested the term "phantom limb". In response to my speech, he said that the situation I described was known as the phantom limb syndrome. An amputee who has lost a limb continues to imagine that he has that limb and even feels pain in the limb. The problem of institutions for administration of justice is similar. Because certain institutions were formed at certain times in history, particularly colonial times, this has given rise to the feeling that these institutions still exist and function more or less as before. In this way they become phantom limbs. ${ }^{7}$

The numerous commissions of inquiry that have been appointed over the past several decades to address human rights concerns in Sri Lanka illustrate this phenomenon perfectly. Paralleling Fernando’s phantom-limb theme, Amnesty International refers to this period as

Basil Fernando, "A three-part study on the crisis in institutions for administration of justice in Sri Lanka and its consequences for the realisation of human rights in Asia”, June 28, 2010, at http://www.article2.org/mainfile.php/0902/377/, referencing Morten Koch Andersen and Basil Fernando, The phantom limb: Failing judicial systems, torture and human rights work in Sri Lanka (Asian Human Rights Commission, 2009), which is available for download at www.ahrchk.net/pub/pdf/ThePhantomLimb.pdf. 
"twenty years of make believe". 8 Outwardly, commissions of inquiry in Sri Lanka are designed to resemble other similar institutions around the world that undertake credible investigations and produce meaningful findings. However, as incarnated in Sri Lanka they currently serve little more purpose than to either relieve domestic pressure or to discredit a previous government. Governments frequently are so brazen as to tailor a particular commission's mandate to specifically restrict its investigations to a time period coinciding with a particular predecessor regime. Evidence is also frequently manipulated. Recommendations are usually ignored and preliminary findings of responsibility are rarely followed through with judicial proceedings. Reports are frequently released to the public only after long delays, or in certain cases not at all. Institutional limitations also abound. For example, there are no built-in safeguards to protect the safety of victims and witnesses. Also, commissioners can be removed at the unreviewable discretion of the president and therefore lack independence.

In 2006, the Commission of Inquiry to Investigate and Inquire into Alleged Serious Violations of Human Rights was established. In response to concerns over the problems associated with past commissions, Sri Lanka's President invited a panel of eleven international experts to supervise the Commission's process and ensure its integrity. This International Independent Group of Eminent Persons (IIGEP) was chaired by the former Chief Justice of the Supreme Court of India, P. N. Bhagwati, and included as members such persons as Bernard Kouchner. Following a series of public statements throughout 2007 expressing serious concerns, the experts of the IIGEP had had enough by March 2008. Citing persistent interference by the Attorney General as well as a lack of transparency, lack of timeliness in proceedings, lack of victim and witness protection, lack of financial independence and lack of cooperative state bodies, they tendered their resignations en masse. Noting further that the recommendations contained in their interim reports had largely gone ignored, they concluded that there was "an absence of political and institutional will on the part of the Government to pursue with vigour the cases under review" ${ }^{\prime 9}$ - definitively putting

\footnotetext{
${ }^{8}$ Amnesty International, Twenty Years of Make Believe: Sri Lanka’s Commissions of Inquiry, 2009, available for download at http://www.amnesty.org/en/library/info/ASA37/005/2009/en

9 See IIGEP, Public Statement, March 6, 2008, available at http://transcurrents.com/tamiliana/archives/566. The Public Statement indicated a final report would be released, which appeared the next month as IIGEP, The Final Report of the IICEP (Final Statement: The Members of the IIGEP Submit Their Concluding Public Statement on the Work of the Commission of
} 
to rest any lingering doubts as to the true nature of Sri Lankan commissions of inquiry. Four Sri Lankan commissioners of the Commission of Inquiry also resigned. ${ }^{11}$ The Attorney General's response to the international experts' criticism was to release a statement accusing the international experts of being involved in an international 'sinister plot'. ${ }^{12}$

We are witnessing what appears to be the same manipulation and deceit with respect to a new commission of inquiry, the Commission on Lessons Learnt and Reconciliation (LLRC), which has been established by the government of Sri Lanka in an effort to deflect criticism and to claim that real efforts are being made to address claims of war crimes and other human rights violations in the final stages of the war with the Liberation Tigers of Tamil Eelam (LTTE). Perhaps the best way to convey the state of affairs is to reproduce at some length an assessment of the Office of War Crimes Issues of US Department of State released in midAugust 2010. One purpose of the report is to narrate the evolution of two purportedly independent investigative bodies established by Sri Lanka since the Department submitted an earlier report to Congress on October 21, 2009; that earlier report identified over 300 reports of incidents in the final months of the war that merited investigation for possible war crimes and crimes against humanity. The following extract employs the device of adding emphasis (by way of italics) in order to direct the reader's attention to facts that, however carefully and even diplomatically expressed, clearly reveal reasons to distrust whether the requisite "political and institutional will" (to return to the language used by the IIGEP) of the government of Sri Lanka is any more present now than during the 2006-2008 episode:

Immediately following the release of the October 2009 Department of State report [on crimes against humanity during the war in Sri Lanka] to Congress, Sri Lankan President Mahinda Rajapaksa appointed a "Group of Eminent Persons" to look into the allegations in the U.S. report and prepare a report for him with its recommendations. The group's report was initially due to President Rajapaksa on December 31, 2009, but the due date was subsequently delayed to April 2010 and then again to July 2010....

Inquiry and Find a Lack of Political Will to Support a Search for the Truth), April 15, 2008, REF: IIGEPPS-006-2006, available for download

at http://www.ruleoflawsrilanka.org/resources/IIGEPnbspSTM.pdf/view.

${ }^{11}$ Human Rights Watch, Sri Lanka: Events of 2008, at http://www.hrw.org/en/node/79245.

${ }^{12}$ Asian Human Rights Commission, SRI LANKA: IIGEP episode, AG's department becoming prosecutor and defender at the same time, Statement AHRC-STM-104-2008, released April 24, 2008, at http://www.ahrchk.net/statements/mainfile.php/2008statements/1483/?print=yes. 
The Department of State concludes that the Group of Eminent Persons was ineffective. The Department of State received conflicting reports about the progress of the Group's inquiry, and confirmed in May that it had not been active for months and that its mandate had been subsumed by the new commission. The Department of State is not aware of any findings or reports of the Group. The Group did not appear to investigate allegations or to make any recommendations pursuant to its mandate.

On May 15, [2010] President Rajapaksa issued a warrant to establish an eightmember commission under the Special Presidential Commissions of Inquiry Law of 1978. The warrant did not explicitly direct the commission to identify violations of internationally accepted norms in conflict situations or to identify those responsible. ... Since then, the Government of Sri Lanka has clarified the mandate of the LLRC in private conversations with U.S. Government officials (although it has not yet done so publicly).

On June 10, the Sri Lankan Ministry of Defense announced that President Rajapaksa had met with the members of the Commission on Lessons Learnt and Reconciliation on June 4. The Ministry's announcement said that the President had informed commission members they had "the responsibility of acting in a forward-looking manner, through focus on restorative justice designed to further strengthen national amity." The statement further noted that the President encouraged the members to "utilize their wide-ranging mandate to fulfil this objective, while always safeguarding the dignity of Sri Lanka.” ...

Evaluating the effectiveness of the CoI should first take into account the history of failings of a series of past CoIs established in Sri Lanka. For example, a 2006 commission charged with investigating sixteen allegations of serious human rights violations ultimately partially investigated only seven of the cases and did not identify any of the perpetrators. An International Independent Group of Eminent Persons (IIGEP) invited by President Rajapaksa to observe the local commission resigned after concluding that the GSL lacked the political will to properly pursue the investigations and that the commission was not meeting international standards in areas such as witness protection, transparency, and financial commitment to the commission. The IIGEP was especially critical concerning a severe conflict of interest by the Attorney General's office, which both represented the GSL and led questioning during hearings. The then incumbent Attorney General, who in that capacity was criticized for obstructing the IIGEP's work, has been appointed as Chairman of the LLRC. ${ }^{13}$

\footnotetext{
${ }^{13}$ Office of War Crimes Issues, US Department of State, Report To Congress on Measures Taken by the Government of Sri Lanka and International Bodies To Investigate Incidents During the Recent Conflict in Sri Lanka, and Evaluating the Effectiveness of Such Efforts, August 11, 2010, available for download at http://www.state.gov/s/wci/srilanka/releases/145884.htm.
} 
The preceding italicized passages speak for themselves in terms of illustrating the prospects for the LLRC acting as a bona fide commission of inquiry. South Africa's Bishop Desmond Tutu had already drawn this conclusion two weeks before the release of the report of the Office of War Crimes Issues:

The government of Sri Lanka needs to show a much greater commitment to achieving meaningful reconciliation. The ongoing persecution and disappearances of human rights activists, journalists and government opponents is truly terrifying. Unfortunately, previous internal commissions have done little to reveal the truth behind human rights abuses. It is doubtful that the President's 'Lessons Learned and Reconciliation Commission' will help Sri Lankans to work towards lasting peace and reconciliation. ${ }^{14}$

With the commissions of inquiry example having set the scene, the remainder of this overview document discusses the overall rule of law situation in Sri Lanka in terms of six themes identified by Basil Fernando as lying at the heart of the current situation of abysmal lawlessness in Sri Lanka:

1. lost meaning of legality;

2. predominance of the security apparatus;

3. disappearance of truth through propaganda;

4. extraordinary concentration of power in the hands of the executive president;

5. destroyed public institutions;

6. zero status of citizens.

These themes provide a useful lens through which to gain an overview of the breakdown of the rule of law in Sri Lanka.

\section{The Lost Meaning of Legality}

Fernando describes the law in Sri Lanka today as an "exercise in futility". He traces this problem back to the 1978 Constitution, which, according to him, "destroyed constitutional law” by negating all checks and balances over the executive president. This has slowly led to

\footnotetext{
${ }^{14}$ Bishop Desmond Tutu, Chairperson, The Elders, statement made as part of The Elders, Sri Lanka's disturbing actions met by 'deafening global silence', Media Release, 3 Aug 2010, available at http://theelders.org/media/mediareleases/sri-lankas-disturbing-actions-met-by-deafening-global-silence.
} 
the irrelevance of the supreme law and, gradually, all other law. Public institutions have also accordingly lost all their power and value. As Fernando puts it:

When there is a loss of meaning in legality, terms such as "judge", "lawyer", "state counsel" and "police officer" are superficially used as in the past; however, their inner meanings are substantially changed. Those who bear such titles no longer have similar authority, power and responsibility as their counterparts had before, when law still had meaning as an organizing principle. ${ }^{15}$

While such individuals hold the same nominal office, the manner in which they discharge their official duties has changed. They no longer carry out their duties in conformity with the rule of law. For instance, under standard criminal procedure there is normally an obligation to investigate all crimes. In Sri Lanka, however, such investigations are carried out selectively. This unofficial expansion of investigative discretion has in turn made possible the nowcommonplace tactic of harassing an enemy or political opponent by causing completely bogus criminal inquiries to be launched. The criminal investigation process has been co-opted from a mode of maintaining law and order to a tool through which not only to withhold protection from citizens but also to actively intimidate and victimize them. For example, when 133 well-known Sri Lankans signed a letter condemning death threats against a civil society activist, the Criminal Investigation Division selectively carried out an investigation not of the death threats but of the propriety of the signatories' actions.

The ineffectiveness of public institutions to maintain law and order has allowed underground elements to take over the functions of 'law enforcement'. More and more actors, both private and institutional, turn to criminal elements to achieve their ends. This is reflected in the "government policy to abduct and kill... [individuals] to be eliminated for political advantage. The method of killing is, like the collecting of debts, now cheaper, quicker and less risky than going through the courts". ${ }^{16}$ As legal redress becomes more the exception than the rule, the meaning of legality becomes corrupted further and further.

\footnotetext{
${ }^{15}$ Fernando, Sri Lanka: Impunity, p 22

${ }^{16}$ Fernando, Sri Lanka: Impunity, 23.
} 


\section{The Predominance of the Security Apparatus}

Beginning with the insurgencies in Sri Lanka in 1971, and continuing through the conflict with the LTTE, the country's security apparatus has emerged as a very powerful actor. This status is not expected to diminish despite the declared end of the conflict a year ago. Many of the 'emergency' measures introduced during the course of the conflict have not been repealed.

The targets of the security apparatus are ordinary citizens with a special focus on trade unionists, journalists, members of civil society organizations, officials and activists in opposition political parties, and people participating in acts of protest. All aspects of Sri Lankan life have now come under surveillance. It is particularly keen to exert control over the electoral process, and does so by targeting the grassroots activities of opposition parties and even ruling party members when internal competition arises.

Legislative measures such as the Prevention of Terrorism Act (PTA) have given the security apparatus much of the power it now holds. However, it is important to note that the security apparatus is by no means constrained by the legal limits of its statutorily conferred authority. With the loss of the meaning of legality there is nothing to prevent it from continuing to do so. A culture has arisen where any calls for accountability are denounced as anti-patriotic and akin to treason, sabotage, or aiding and abetting terrorism.

Accordingly, extrajudicial disappearances, torture, and killings are commonplace and, in the name of counter-terrorism through total war, atrocities against both civilians and surrendered LTTE fighters were equally commonplace in the final months of the war. ${ }^{17}$ Meanwhile over

\footnotetext{
${ }^{17}$ See, for example, (1) International Crisis Group, War Crimes in Sri Lanka, May 17, 2010 , available for download at http://www.crisisgroup.org/en/regions/asia/south-asia/sri-lanka/191-war-crimes-in-srilanka.aspx - "The Sri Lankan security forces and the Liberation Tigers of Tamil Eelam (LTTE) repeatedly violated international humanitarian law during the last five months of their 30-year civil war. Although both sides committed atrocities throughout the many years of conflict, the scale and nature of violations particularly worsened from January 2009 to the government's declaration of victory in May. Evidence gathered by the International Crisis Group suggests that these months saw tens of thousands of Tamil civilian men, women, children and the elderly killed, countless more wounded, and hundreds of thousands deprived of adequate food and medical care, resulting in more deaths. The eventual destruction of the LTTE militarily came at the cost of immense civilian suffering and an acute challenge to the laws of war. It also undermined the credibility of the United Nations and further entrenched a bitterness among Tamils in Sri Lanka and elsewhere which may make a durable peace elusive. Now a number of other countries are
} 
considering 'the Sri Lankan option' - unrestrained military action, refusal to negotiate, disregard for humanitarian issues - as a way to deal with insurgencies and other violent groups.”; (2) Human Rights Watch, Recurring Nightmare: State Responsibility for "Disappearances" and Abductions in Sri Lanka, March 2008, available for download at http://www.hrw.org/en/reports/2008/03/05/recurring-nightmare-0 - "Hundreds of enforced disappearances committed since 2006 have already placed Sri Lanka among the countries with the highest number of new cases in the world. The victims are primarily young ethnic Tamil men who 'disappear' —often after being picked up by government security forces in the country's embattled north and east, but also in the capital Colombo. Some may be members or supporters of the LTTE, but this does not justify their detention in secret or without due process. Most are feared dead. In the face of this crisis, the government of Sri Lanka has demonstrated an utter lack of resolve to investigate and prosecute those responsible.” (p 5); (3) Report of the Special Rapporteur on torture and other cruel, inhuman or degrading treatment or punishment, Manfred Nowak: MISSION TO SRI LANKA, UN Doc. A/HRC/7/3/Add.6, 26 February 2008, available for download at http://www2.ohchr.org/english/bodies/hrcouncil/7session/reports.htm - "70. ...[I]n the context of detention orders under the Emergency Regulations and in particular with respect to LTTE suspects, the clear majority of all detainees interviewed by the Special Rapporteur complained about a broad variety of methods of torture, some extremely brutal. In many cases, these allegations were corroborated by forensic evidence. The considerable number of clearly established cases of torture by TID and other security forces, together with various efforts by TID to hide evidence and to obstruct the investigations of the Special Rapporteur, leads him to the conclusion that torture has become a routine practice in the context of counter-terrorism operations, both by the police and the armed forces.... 71. Methods of torture reported included beating with various weapons, beating on the soles of the feet (falaqa), blows to the ears (telephono), positional abuse when handcuffed or bound, suspension in various positions, including strappado, "butchery", "reversed butchery" and "parrot’s perch" (or dharma chakara), burning with metal objects and cigarettes, asphyxiation with plastic bags with chilli pepper or gasoline, and various forms of genital torture. This array of torture finds its fullest manifestation at the TID detention facility in Boosa. The Special Rapporteur is also shocked by the brutality of some of the torture measures applied to persons suspected of being LTTE members, such as burnings with soldering irons and suspension by the thumbs. The latter method was allegedly applied by the army."; (4) Technical Note prepared by the Special Rapporteur on extrajudicial, summary or arbitrary executions, Mr. Philip Alston, in relation to the authenticity of the "Channel 4 videotape", January 2010, available for download at http://www2.ohchr.org/english/issues/executions/index.htm - "On 25 August 2009, a United Kingdom television station released video footage which appears to show the summary execution of Tamils by Sri Lankan soldiers. A group named Journalists for Democracy in Sri Lanka claimed that the killings had been filmed in January 2009 by a Sri Lankan soldier with a mobile phone. This was at a time when the international media did not have access to the conflict zone. Since the video's release, the Government of Sri Lanka has claimed that the video is a fake. Over the past four months, I have been engaged in a series of communications with the Government about this video, in which I requested it to conduct an independent investigation. While the Government initially refused to do so, on 7 September 2009, it issued a response stating that it had commissioned four separate investigations, and that they 'have now scientifically established beyond any doubt that this video is a fake'. At the time, I expressed concern about the objectivity of the investigations, in part because two of the "independent experts" worked for the Sri Lankan armed forces. Some of the reports seemed more impressionistic than scientific, and I have never been provided the full version of the reports. I decided that it was incumbent upon me to commission independent and impartial evaluations of the videotape. I retained three experts: in forensic pathology ..., forensic video analysis ...., and firearm evidence ..... Together, the reports by these experts strongly suggest that the video is authentic....While there are some unexplained elements in the video, there are strong indications of its authenticity. In addition, most of the arguments relied upon by the Government of Sri Lanka to impugn the video have been shown to be flawed. In light of these conclusions, and of the persistent flow of other allegations concerning alleged extrajudicial executions committed by both sides during the closing phases of the war against the LTTE, I call for an independent inquiry to be established to carry out an impartial investigation into war crimes and other grave violations of international humanitarian and human rights law allegedly committed in Sri Lanka.” 
camps accused of being members of the LTTE. ${ }^{18}$ They have not been formally charged, nor have they been allowed legal representation or access to any procedure to review the legality of their detention. Allegations of mistreatment also abound, but no humanitarian agencies not even the International Committee of the Red Cross - have been allowed access to the detainees, a flagrant violation of international law.

\section{The Disappearance of Truth through Propaganda}

Years of conflict have exerted a calamitous effect on the propagation of truth in Sri Lanka. Equal in strategic importance to territorial struggle during the conflict was the struggle for control over information. The military and the LTTE both vied to cast their polarized propagandistic perspectives as the single version of the truth.

The state has learned to excel at creating and controlling a single, official version of the truth. Society, for its part, has largely accepted the state's self-anointed role as arbiter of truth and falsehood. As Fernando observes, "those who run the media also usually comply with

\footnotetext{
${ }^{18}$ Human Rights Watch, Legal Limbo - The Uncertain Fate of Detained LTTE Suspects in Sri Lanka, 2 February 2010 - “ The Sri Lankan government is currently detaining at least 11,000 people, including more than 550 children, in so-called "rehabilitation centers." These individuals, said to be associated with the separatist Liberation Tigers of Tamil Eelam (LTTE), were among the almost 300,000 displaced persons confined in detention camps in the final months of the armed conflict with the LTTE. The government has routinely violated the detainees' fundamental human rights, including the right to be informed of specific reasons for arrest, the right to challenge the lawfulness of the detention before an independent judicial authority, and the right of access to legal counsel and family members. The authorities' consistent failure to inform families of the basis for the detainees' arrest and their whereabouts raises serious concerns that some detainees may have been victims of torture and ill-treatment, which are more likely to take place where due process of law is lacking and which have long been serious problems in Sri Lanka. Given the lack of information about some detainees, there is also a risk that some may have been "disappeared."...Concerns about the fate of detainees are aggravated by Sri Lanka's appalling record of enforced disappearances."; and International Commission of Jurists, Beyond Lawful Constraints: Sri Lanka's Mass Detention of LTTE Suspects, September 2010, available for download at http://www.icj.org/default.asp?nodeID=349\&sessID=\&langage=1\&myPage=Legal_Documentation\&id=2 $\underline{3159}$ - "This report addresses human rights concerns arising from what may be the largest mass administrative detention anywhere in the world. The Government of Sri Lanka is currently holding approximately eight thousand individuals under administrative detention without charge or trial. They are alleged former associates of the LTTE and therefore required to undergo 'rehabilitation' under Sri Lanka's 2005 emergency regulations. Hundreds of others have been screened and held separately for criminal prosecution. The ICJ is concerned that the Government's ‘surrendee' and 'rehabilitation' regime fails to adhere to international law and standards, jeopardizing the rights to liberty, due process and fair trial. There are also allegations of torture and enforced disappearance. Access required for reliable and accurate monitoring by international agencies, including the International Committee of the Red Cross (ICRC), has been denied.”
} 
demands to reproduce and disseminate government propaganda. Those who do not comply are threatened”. IBAHRI notes that the media have reached this point through years of intimidation. Journalistic voices critical of the government's security measures have been routinely named by the Ministry of Defence as 'Tiger sympathisers', 'LTTE supporters' or 'terrorists'. Frequently, this is a precursor to a threat or physical attack against the journalists. At least 14 media workers have been murdered since the beginning of 2006, with many others receiving death threats and suffering physically assaults or vandalised properties. In many cases journalists are forced to flee the country. The state has also proven adept at using institutional channels to subvert press freedom.

For instance, in August 2009, J.S. Tissainayagam, a journalist who had written critically of the government's military campaign, was sentenced to 20 years of hard labour in what was the first conviction of a journalist for his writings under the PTA. A high-profile journalist who was critical of government conduct, Lasantha Wickrematunge, was assassinated in January 2009; he had prepared an editorial to be published in the event of his murder in which the following words appears: "no other profession calls on its practitioners to lay down their lives for their art save the armed forces and, in Sri Lanka, journalism.... Electronic and print-media institutions have been burnt, bombed, sealed and coerced. Countless journalists have been harassed, threatened and killed. It has been my honour to belong to all those categories and now especially the last”. ${ }^{19}$ On 24 January 2010, journalist Prageeth Ekneligoda disappeared and has not been heard of since; Prageeth regularly contributed to LankaeNews web site and is a political analyst and a cartoonist known for his outspoken views critical of the government. These are just three of many examples that could have been chosen. So dismal is the situation, in fact, that Reporters Without Borders ranked Sri Lanka 162 of 175 countries in its 2009 Press Freedom Index. ${ }^{20}$

\footnotetext{
19 Lasanth Wickrematunge, “And Then They Came for Me”, The Sunday Leader, January 11, 2009 at http://www.thesundayleader.lk/archive/20090111/editorial-.htm.
}

\footnotetext{
${ }^{20}$ See more generally Reporters Without Borders at http://en.rsf.org/sri-lanka.html for a large number of entries of incidents in Sri Lanka relating to the freedom and security of journalists. For a digest of monthly updates on developments and incidents in Sri Lanka between September 2003 and September 2010, see the International Crisis Group Crisis Watch at http://www.crisisgroup.org/en/publicationtype/crisiswatch/crisiswatch-database.aspx?CountryIDs=\{E3AEAB0F-4DC7-4926-95103165AA4F182B\}.
} 
The legal profession has been similarly conditioned. On 28 January 2009, Amitha Arayatne, who had acted in several prominent human rights cases, received death threats from police officers. Two days later, his house was burned. Such incidents have been effective at reducing the number of lawyers willing to take on human rights cases. In March 2009, the lawyer representing Sunil Shantha, who was accusing the police of torture, suddenly withdrew from the case on account of threats from police.

As a result of these dynamics, there is a general level of societal disinterest in truth itself. When the truth is so cynically manipulated, Fernando explains, "people cease expecting to know the truth of anything.” As a result, government spokespeople automatically deny any allegations of human rights violations, knowing that no one will come forward to speak what they know due to fear or a sense of sheer futility.

\section{The Concentration of Power in the Hands of the President}

Fernando attributes the current breakdown of the rule of law in Sri Lanka in part to the high concentration of power conferred upon the executive president under the 1978 Constitution. Under that document, the president gained:

- absolute immunity from lawsuits of any kind;

- all the powers of cabinet, including control over the civil service;

- the power to appoint or dismiss the prime minister at will; and

- the ability to dissolve parliament a year after its election.

According to Fernando, the underlying principle of such a heavy concentration of power in the hands of the presidency is rooted in the belief that such a system is the only effective way to govern the country. However, with all the checks and balances on executive presidential power removed, this system has also exposed the office of president to abuses of power. The concentration in the executive presidency of responsibilities far greater than one person can possibly manage has led to poor oversight and dysfunction in public institutions. This has exacerbated the breakdown in the rule of law. 
To partially address this problem, Parliament in 2001 passed the $17^{\text {th }}$ Amendment to the Constitution. This created a Constitutional Council with the power to recommend or approve the appointment of a number of key positions within the public service. These positions included the Attorney General, the Inspector General of Police and the Chief Justice. The passing of the amendment was intended to restore a measure of independence to institutions of governance as the appointment process had become too politically biased in favour of the president. However, the Constitutional Council has been in abeyance since 2005 when the term of the first Council lapsed and the President refused to appoint successors who had been selected by the various parties in accordance with the constitution. The President's failure to appoint cannot be directly challenged in court due to his legal immunity under Article 35 of the Constitution. Nevertheless, litigation has been launched alleging that the nonimplementation of the 17th Amendment is a violation of the constitutional right to equality before the law. The power of the Chief Justice to make the appointments, if the President refuses to do so, is also unresolved. According to the IBAHRI, "the non-implementation of the $17^{\text {th }}$ Amendment represents one of the most critical unresolved rule of law issues in the country" 21 .

A culmination of this concentration of vast and unchecked power in the hands of one person is plainly evident in the successful initiative of President Rajapaksa to have Parliament adopt an $18^{\text {th }}$ Amendment to the Constitution this month (September 2010). The $18^{\text {th }}$ amendment removes the current constitutional limitations on the number of terms that a president can serve and abolishes the Constitutional Council altogether. It vests in the President an unlimited power of appointment of the entire membership of a large number of crucial standing commissions as well as of key office-holders, subject only to a duty to "seek the observations" of five people - the Prime Minister, the Speaker, the Leader of the Opposition, a nominee of the Prime Minister, and a nominee of the Leader of the Opposition. ${ }^{22}$

\footnotetext{
${ }^{21}$ IBAHRI, Justice in Retreat, pp 23-24.

${ }^{22}$ See the downloadable PDF of an An Act to Amend the Constitution of the Democratic Socialist Republic of Sri Lanka, L.D. O 19/2010, at http://www.thesundayleader.lk/2010/09/03/proposed-18th-amendment-tothe-sri-lankan-constitution-full-text/. The commissions whose entire memberships will be decided by the President are: the Human Rights Commission of Sri Lanka, the National Police Commission, the Public Service Commission, the Election Commission, the Permanent Commission to Investigate Allegations of Bribery and Corruption, the Finance Commission, and the Delimitation Commission. The office-holders who will be appointed solely by the President are: the Chief Justice of the Supreme Court and each judge on that court; the Chief Justice of the Court of Appeal and every judge on that court; the Attorney-General;
} 


\section{Destroyed Public Institutions}

Fernando argues that through the combined effect of the aforementioned four elements, the administration of justice in Sri Lanka has been effectively destroyed. This topic has been the subject of much of the work of the Asian Human Rights Commission (AHRC) and the Asian Legal Resource Centre (ALRC). In his book, Fernando reviews this work in order to catalogue the descent into disgrace of the police, the Attorney General's department, and the judiciary. In each case, the institution has degenerated to the point where today it appears to serve no other purpose than to provide cover for abuses of power and rights violations perpetrated by the state. As a result, "there is nothing sacrosanct or predetermined about any institutional practices now, and the citizen who goes before public institutions knows not what to expect”23.

Pinto-Jayawardena identifies two factors in particular that lie at the root of Sri Lanka's failed public institutions. These are political interference from the executive, and a lack of public resources. $^{24}$

the Auditor-General; the Parliamentary Commissioner for Administration (Parliament's Ombudsman); the Secretary-General of Parliament; and members of the Judicial Service Commission (with, for some reason, the specific exception of the Chairman).

${ }^{23}$ Fernando, Sri Lanka: Impunity, p 27.

${ }^{24}$ Apart from the report cited earlier (Pinto-Jayawardena, The Rule of Law in Decline in Sri Lanka- Study on the Prevalence, Determinants and Causes of Torture and Other Forms of Cruel, Inhuman and Degrading Treatment), see also: Kishali Pinto-Jayawardena, Post-War Justice in Sri Lanka: Rule of Law, the Criminal Justice System and Commissions of Inquiry (International Commission of Jurists, January 2010), available for download at http://www.icj.org/default.asp?nodeID=349\&sessID=\&langage=1\&myPage=Legal Documentation\&id=2 2931; International Crisis Group, Sri Lanka’s Judiciary: Politicised Rights, Compromised Courts, June 28, 2009, available for download at www.crisisgroup.org/.../sri-

lanka/172_sri_lankas_judiciary_politicised_courts_compromised_rights.ashx; and Françoise Hampson, Leif Sevón and Roman Wieruszewski, The Implementation of Certain Human Rights Conventions in Sri Lanka: Final Report, 30 September 2009, Expert report prepared at the request of the European Commission, available for download at http://trade.ec.europa.eu/doclib/docs/2009/october/tradoc_145153.pdf. 
The key to any successfully functioning judiciary is judicial independence. However, the judiciary in Sri Lanka cannot be said any longer to enjoy judicial independence. This is a change that has occurred over the past decade or so. As Pinto-Jayawardena comments,

Most importantly, despite the terror of the [nineteen] eighties, there were the courts....

The point is that the judiciary (largely as a whole) kept their integrity intact during that period. A constituency of public opinion recognised the core importance of constitutional institutions in general and an independent judiciary in particular. This faith was kept alive and enabled judges to stand up against aggressive political authority, sometimes in the most dangerous of moments. ${ }^{26}$

Many observers point to the 1999 appointment of then-Attorney General Sarath N. Silva to the office of Chief Justice as a watershed moment in the degeneration of the judiciary. $\mathrm{Mr}$ Silva had close ties to the then-President. Once a credible defender of fundamental rights and an important check on executive power, the office of Chief Justice has decayed to its current weakened and docile state. Silva's appointment came amidst a flurry of executive backlash against a Supreme Court which it saw as unduly intrusive in government affairs. The appointment was accompanied by a perceptible shift in the Court's attitude towards fundamental rights petitions. According to the IBAHRI report, Chief Justice Silva had a domineering personality which he used to maximum effect by assigning the most politically sensitive cases to himself and the most junior judges. ${ }^{27}$ For example, a petition against his appointment to the Supreme Court was dismissed by a five-judge bench comprising (by his own order) himself and the four most junior judges. On two other occasions, Parliament attempted to effect his removal with impeachment motions, only to be thwarted by the President's summary dissolution of the legislature.

The executive also interferes habitually in the affairs of the judiciary. For instance, the IBAHRI notes that, in one speech in 2008, the President Rajapaksa issued thinly-veiled threats of violence and impeachment to the judges of the Supreme Court. ${ }^{28}$ These threats must be read against the lack of institutional guarantees for judicial independence: any judge of the Court of Appeal or Supreme Court can be removed by an order of the president

\footnotetext{
26 "Death chant for democracy," The Sunday Times (of Sri Lanka), September 12, 2010, at http://sundaytimes.lk/100912/Columns/focus.html.

${ }^{27}$ IBAHRI, Justice in Retreat, p 85.

${ }^{28}$ IBAHRI, Justice in Retreat, p 31.
} 
supported by a simple majority in Parliament. The situation has not improved since the release of the IBAHRI report in 2009. The lack of judicial independence for the judiciary has led to its politicization, and is just one example of the erosion of public institutions in Sri Lanka.

Institutions which are set up to act as checks upon state action lack proper insulation from political interference. The section above has already described how the Constitutional Council, designed to inject a measure of impartiality in the heavily politicized appointments process, was undermined by the executive. Various elements of the state security apparatus are not properly insulated from institutions that are ostensibly designed to investigate and address complaints against them. For example, the unit responsible for investigating allegations of torture against police is composed of police officers who are often transferred in and out of the unit. They are effectively assigned to investigate their own colleagues. Under such circumstances, it is impossible to expect fully independent and impartial investigations. The result, unsurprisingly, has been a near-complete failure to follow up allegations of torture against the police.

The lack of resources is the second major problem that severely compromises the capacity of public institutions, including the courts, to fulfil their roles. Due to lack of resources, public institutions are understaffed. Their personnel lack the proper training for their posts. This only adds to the Sisyphean challenge of resurrecting these institutions from their already dysfunctional state.

\section{The Zero Status of Citizens}

As the performance of the country's public institutions has fallen towards zero, so in effect has the status of its citizens. Where there are no effective public institutions there can be no meaningful individual rights. The rights that citizens enjoy under the statute books have no actual relevance because there is no effective mechanism to guarantee them. As the nation's public institutions have vanished, so has any conception of Sri Lankans’ individual rights.

Perhaps the starkest example of this zero status can be seen in the detention camps. At the height of the situation, hundreds of thousands of internally displaced persons were detained. 
The operation of these camps contravened a number of obligations within international human rights law and humanitarian law. ${ }^{30}$ The situation highlighted the current reality in Sri Lanka - that its citizens are subject not to the rule of law, but to the naked political power of the ruling government.

Although the detention camps provided a dramatic illustration, it is important to reiterate that it is not just internally displaced persons in Sri Lanka that have zero status. All citizens right up to the members of the privileged elite have a zero status. For these individuals, even their relative wealth and power cannot afford them access to public institutions that have been destroyed. The rule of law has vanished with respect to all Sri Lankans. Fernando chronicles how, from time to time, members of the ruling class are surprised to learn that their position in the hierarchy does not make them invulnerable to (legally) arbitrary treatment. Often - as in the case of the prosecution for sedition of General Fonseka - these individuals were themselves active in the repressive state structure before the system turned against them.

\section{Summary}

In broad strokes, the collapse of the rule of law in Sri Lanka can be reduced to the following. The legitimacy of Sri Lanka's public institutions has been destroyed through years of undue political interference from the executive and through the involvement of public institutions in the perpetration of repression. Mechanisms that could partially address deficiencies in institutional independence, such as the Constitutional Council, the courts, or commissions of inquiry, have been systematically sabotaged by the executive. Further, perceived security threats have given the executive an excuse to maintain much of the power it now holds. As a result of this situation, there is no longer an expectation on the part of Sri Lankans that their public institutions will operate according to the rule of law. At the same time, the concept of individual rights itself has also been lost. Sri Lankans' expectations that they will have anything beyond zero status have also gradually been eroded. When this mentality pervades not just the general public but also those who hold office in public institutions, the rule of law is extensively compromised. Meanwhile, because of the disappearance of truth as a public

\footnotetext{
${ }^{30}$ See Amnesty International, Unlock the Camps in Sri Lanka: Safety and Dignity for the Displaced Now, August 2009, available for download at http://www.amnesty.org/en/news-and-updates/news/unlockcamps-sri-lanka-20090807.
} 
enterprise - effected by years of government propaganda, manipulation and outright intimidation of the media - alongside a climate of fear, there is little organized pressure on the government to address the situation. In all of this, the breakdown of the institutional rule of law feeds into and feeds from the mindsets of both the persons who staff public institutions and, increasingly, Sri Lankan society more generally. 